VLADIMÍR MAŇAS, NICOLAUS ZANGIUS: HUDEBNÍK PŘELOMU I6. A I7. STOLETÍ. NA STOPĚ NEZNÁMÉMU

Brno 2020 Masarykova univerzita (= Spisy Filozofické fakulty Masarykovy univerzity = Opera Facultatis philosophicae Universitatis Masarykianae 504), ss. 204 + I CD audio. ISBN 978-80-210-9716-2; 978-80-210-9717-9, online https://digilib.phil.muni.cz/ handle/11222.digilib/143685

$\mathrm{M}$ onografie poświęcone postaci jednego kompozytora nie są na rynku wydawniczym zjawiskiem częstym. Dlatego też, z tym większym zainteresowaniem powinna spotkać się biografia Nicolausa Zangiusa autorstwa Vladimíra Maňasa historyka i muzykologa, obecnie adiunkta w Instytucie Muzykologii Uniwersytetu Masaryka w Brnie. Książka została wydana w minionym roku w ramach projektu „Výzkumné sondy $\mathrm{k}$ dějinám hudební kultury na Moravě, především v Brně, část VII" przez macierzystą uczelnię autora ${ }^{\mathrm{I}}$.

W swoich dotychczasowych, długoletnich badaniach Maňas skupiał się przede wszystkim na życiu muzycznym Moraw i Górnego Śląska w XVI i XVII w., w tym historii tamtejszych parafii i związanych z nimi duchownych ${ }^{2}$. Impulsem do zrekonstruowania kariery Zangiusa - kapelmistrza, kompozytora, muzyka, impresaria, a nawet agenta działającego m.in. na zamku książęcym w Iburgu, w kościele Mariackim w Gdańsku, rezydencjach Liechtensteinów

1 Masarykova univerzita, www.muni.cz/vyzkum/ projekty/54568, dostęp 23 V 2021.

2 Wybrane publikacje: Vladimír Maňas, „Dějiny a konfesní proměny holešovské farnosti do poloviny 19. stoletî", w: Holešov. Mèsto ve spirálách času, red. Zdeněk Fišer, Brno 2018, s. 377-404; tegoż, „«... viell fürsten halten ein Musica». Musik und Musiker am Hofe der Fürsten von Liechtenstein im 17. Jahrhundert", Studia historica Brunensia 64 (2017) nr 1, s. 189-215; tegoż, „Hudební inventáre farního kostela v Jablonném v Podještědí (1664 a 1715)", Opus musicum 49 nr 6 (2017), s. 29-39; tegoż, „Dobový soupis motet Nicolause Zangia z roku 1608 a jeho souvislosti", Opus musicum 48 nr 1 (2016), s. 6-21. na Morawach oraz siedzibie elektorów brandenburskich w Berlinie - była analiza materiałów z książęcego archiwum Liechtensteinów. Źródła te dostarczają informacji na temat pomijanego dotychczas $w$ literaturze ${ }^{3}$ okresu działalności kompozytora na dworze Karola Liechtensteina w pierwszej dekadzie XVII wieku. Maňas śledzi, a czasem nawet tropi losy Zangiusa od jego narodzin, aż do śmierci, poprzez kraje i ośrodki, starając się zweryfikować lub zinterpretować skrawki informacji, którą to czynność sam we wstępie (rozdz. I „Úvod”, s. II-I7) przyrównuje do „nawlekania na nitkę koralików nierównej wielkości” (s. II). W kolejnym rozdziale (rozdz. 2 "Nicolaus Zangius, jinak také Niklas Zange, Zanchi, Zenggl, Zenchel”, s. 19-77) podejmuje dyskusję na temat miejsca i daty urodzenia kompozytora, sugerując, że był krewnym Narcissusa Zängela - kompozytora pochodzącego z Augsbur$\mathrm{ga}^{4}$. Następnie omawia etapy działalności badanego przez siebie autora. Informacji szuka w przekazach archiwalnych, drukach muzycznych, wnioskuje $\mathrm{z}$ dedykacji oraz danych biograficznych innych osób z bliższego i dalszego otoczenia kompozytora oraz tytułów, jakimi był określany lub sam się posługiwał. Doniesienia badaczy przedwojennych i powojennych konfrontuje ze współczesnymi ustaleniami. Te ostatnie, jak na przykład błędnie określone miejsce i datę

3 Hans Sachs, Nikolaus Zange's weltliche Lieder, Universität Wien 1934 (dysertacja doktorska).

4 Andreas Traub, Eberhard Stiefel, „Zängel, Narcissus”, w: MGG Online, red. Laurenz Lütteken, https://www.mgg-online.com/mgg/stable/21484, dostęp 23 V 2021. 
śmierci Zangiusa, podawane m.in. w publikacjach encyklopedycznych', weryfikuje. W rozdziale trzecim („Zangiovo dílo a jeho šírenî”, s. 79-II4) porzuca opis chronologiczny na rzecz analizy informacji na temat małoformatowych druków dedykowanych, epitalamiów, kolekcji drukowanych oraz rękopisów autorstwa Zangiusa. Przedstawia je w kontekście zjawiska daru muzycznego, jego znaczenia oraz związanych z nim relacji społecznych, w jakie zaangażowani byli kompozytorzy i kapelmistrzowie działający na przełomie XVI i XVII wieku. Przedostatni, czwarty rozdział - „Musica” (s. II5-I49) - poświęcony jest rozumieniu tego pojęcia w czasach działalności Zangiusa. Jest ono punktem wyjścia dla opisu składu osobowego, repertuaru oraz roli zespołu muzycznego wojewody morawskiego Karola Liechtensteina, w którym Zangius piastował posadę kapelmistrza najpewniej przez dwa lata od roku I604. Niedosyt informacji na temat twórczości kompozytora w pewnej mierze zaspokaja szczególnie ciekawy, choć z racji niewielkiej objętości określony jako dodatek, rozdział ostatni. Zawarta w nim krótka analiza formalna wybranych utworów w zestawieniu $\mathrm{z}$ informacjami na temat dotychczasowych nagrań, ówczesnej i współczesnej praktyki wykonawczej oraz możliwości i ograniczeń związanych z określonym doborem obsady i zastosowanych transpozycji, stanowi wstęp do dołączonych do książki nagrań siedemnastu kompozycji Zangiusa - głównie łacińskich motetów ze zbioru Cantiones sacrae ${ }^{6}$ w wykonaniu En-

5 Andreas Waczkat, „Zangius, Nikolaus”, w: ibid., https://www.mgg-online.com/mgg/stable/16480, dostęp 23 V 2021; Walter Blankenburg, Dorothea Schröder, „D. Zangius [Zange], Nikolaus”, w: Grove Music Online, https://www-1oxfordmusiconline-1com -100008c9k1f96.han.buw.uw.edu.pl/grovemusic/ view/10.1093/gmo/9781561592630.001.0001/ omo-9781561592630-e-0000030834, dostęp $23 \mathrm{~V}$ 2021.

6 Wiedeń 1612 Ludwig Bonnoberger, RISM A/I Z 44. semble Versus i Capella Ornamentata pod dyrekcją autora.

Książka Maňasa to biografia pisana przede wszystkim przez historyka. Ze swobodą nakreśla on szeroki, czasami nawet aż nadto, kontekst dziejowy i społeczny, w jakim funkcjonował Nicolaus Zangius. Dogłębna analiza materiałów archiwalnych, rachunków oraz dotychczasowych ustaleń, a także badania prozopograficzne pozwalają mu stosunkowo wyraźnie, jak na dostępne źródła, scharakteryzować etapy życia kompozytora. Przedstawia go jako człowieka żyjącego w przededniu wojny trzydziestoletniej, którego sytuacja życiowa i usposobienie zmuszały do częstych podróży i zmian miejsca zamieszkania oraz pracodawców. Historyczne predyspozycje i predylekcje autora ukazuje szczególnie rozdział „Musica”. Działalność Zangiusa na dworze Karola Liechtensteina wydaje się stanowić tylko pretekst do przedstawienia wyników kwerend i badań nad książęcymi archiwaliami, w tym rachunkami i inwentarzami. Pozwala to Maňasowi na częściowe odtworzenie składu osobowego zespołu, etapów jego tworzenia i określenie roli, jaką odegrał w tym Zangius, na którego lata działalności kapelmistrzowskiej - jak wnioskuje autor - przypadają czasy świetności zespołu.

Książka Maňasa to biografia pisana także przez muzykologa. Jej głównym bohaterem jest kompozytor, muzyk i kapelmistrz, którego twórczość związana była bezpośrednio $\mathrm{z}$ obejmowanym stanowiskiem lub zależnością zawodową, w jakiej się znajdował lub chciał się znaleźć. Dedykacje zawarte w niektórych drukach pozwalają sądzić, że Zangius starał się za ich pomocą uzyskać posadę m.in. w służbie rady miasta Lüneburga ${ }^{7}$, bądź przypuszczać, że w ten sposób chciał on wyrazić wdzięczność dla Jeronyma Makovskiego za pomoc w uzyskaniu tytułu

7 Schöne newe außerlesene geistliche und weltliche Lieder, Frankfurt n. Odrą 1594 Andreas Eichhorn, RISM A/I Z 31. 
i niemałej pensji sługi cesarza Rudolfa $\mathrm{II}^{8}$. Autor śledzi działania nie tylko głównego bohatera, lecz także kompozytorów i muzyków z jego otoczenia, takich jak Johannes Wanning, Jakob Schmidt, Andreas Hackenberger, czy Matthaeus Läder. Na ich podstawie wyciąga wnioski co do pozycji społecznej Zangiusa, uprawianych przez niego gatunków muzycznych, bądź wstępnego oglądu pośmiertnej recepcji jego twórczości. Analizując instrumentarium zespołu Karola Lichtensteina oraz zespołu berlińskiego, przedstawia je w kontekście ówczesnej terminologii oraz praktyki wykonawczej.

W książce Maňasa widoczne jest także jego doświadczenie bibliotekarskie. Autor niezwykle sprawnie porusza się w historii i przemieszczeniach zbiorów oraz materii bibliotecznej, a co za tym idzie także typografii druków muzycznych przełomu XVI i XVII wieku. Poza materiałem muzycznym i jego typologią analizuje zawarte w nich parateksty, miejsca wydania i datowanie, formy zapisu, wygląd kart tytułowych oraz format druków.

Biografia Zangiusa to książka pisana również przez muzyka. Dzięki doświadczeniu wykonawczemu Maňas wymienia przyczyny, dla których muzyka Zangiusa nie jest obecnie repertuarem pierwszego wyboru podczas układania programów koncertów czy nagrań. Przedstawia także dyskografię utworów Zangiusa od roku 1972 do 2016, wypunktowując słabe i mocne strony poszczególnych interpretacji. We wstępie do dołączonych do książki nagrań uzasadnia wybór repertuaru oraz aparatu wykonawczego. Powołuje się na argumenty właściwe czynnym muzykom, obeznanym w renesansowej praktyce wykonawczej, związane $\mathrm{z}$ tempem, fakturą i ambitus melodii i świadczące o dużej wyobraźni brzmieniowej autora (zob. rozdz. 5 „Appendix: znějící

8 Kurtzweilige newe teutsche weltliche Lieder, Kolonia 1603 Gerhard Grevenburch RISM A/I Z 36. podoby Zangiových skladeb aneb obsáhlejšsi předmluva k nahrávce", s. I5I-I55).

Ogromną wartością dodaną omawianej monografii jest osadzenie twórczości i życia Zangiusa w szerszym kontekście kulturowym, wyznaczanym przez pojęcia daru i wzajemności. Oparcie tych refleksji na myśli socjologicznej, ekonomicznej oraz antropologicznej Marcela Maussa, Karla Polanyiego i Annette Weiner' ${ }^{9}$ pozwoliło stworzyć Maňasowi nietuzinkową narrację zbudowaną wokół dedykacji, relacji zawodowych i towarzyskich. To książka będąca przykładem prezentacji badań mikrohistorycznych, wbrew pozorom bardzo częstych w muzykologii.

Nie jest to jednak monografia sensu stricto. Ma ona konstrukcję „nieuchronnie fragmentaryczną" (s. II). Być może właśnie dlatego rozważania dotyczące aktorów drugiego planu niekiedy odciagają uwagę autora od głównego bohatera, a chęć zapełnienia białej plamy dotyczącej działalności Zangiusa na dworze Liechtensteina nie zawsze tłumaczy rozbudowane opisy dotyczące historii i powiązań aktorów drugoplanowych. Pomimo ogromnej skrupulatności w dociekaniach źródłowych uwadze autora umknęły m.in. dwa przekazy utworów Zangiusa: powstała już po śmierci kompozytora tabulatura pelplińska (PL-PE Ms. 308) z odpisem motetu Conratulamini nunc omnes ${ }^{\mathrm{I}}$ oraz zawierajaca zidentyfikowany ostatnio przez Marcina Szelesta przekaz motetu Tota pulchra es w tabulaturze braniewsko-oliwskiej (LT-Vn FIs 284) ${ }^{\text {II }}$. W samej bibliografii zabrakło również tabulatury legnickiej Libr. Mus Ioo (PL-Wn Mus.326), choć jest ona wspomnia-

9 Autor zapewne ma na myśli tę badaczkę, powołując się na „Anette Weinert” (s. 80, 82, 200).

10 The Pelplin Tablature. A Thematic Catalogue, red. Adam Sutkowski, Alina Osostowicz-Sutkowska, Graz-Warszawa 1963 (= Antiquitates Musicae in Polonia 1), s. 474, 477.

11 Tabulaturae Braunsbergenses-Olivenses, red. Marcin Szelest, Warszawa 2021 (= Fontes Musicae in Polonia, C/XXV), s. 39, 117, 398. 
na w książce jako jedyny znany kompletny przekaz motetu Ecce quam bonum.

Powyższe uwagi nie umniejszają jednak wartości omawianej książki. Jest ona cenną, oryginalną prezentacją wyników śledztwa w sprawie jednej z wielu ciekawych, choć pomniejszych postaci składających się na coraz pełniejszy obraz historii muzyki czasów wczesnonowożytnych. Z pewnością stanowi ona doskonały punkt wyjścia do badań nad recepcją twórczości Zangiusa. Pokazuje również jak wiele możliwości daje włączanie do badań historycznych metodologii innych nauk.

Sonia Rzepka Uniwersytet Warszawski

\section{ANDREA MARIANI, INVENTORIA RERUM MUSICALIUM DOMUM SOCIETATIS IESU IN POLONIA ET LITUANIA TEMPORE SUPPRESSIONIS}

Warszawa 2020 Instytut Muzykologii Uniwersytetu Warszawskiego, Wydawnictwo

Naukowe Sub Lupa (= Fontes Musicae in Polonia, A/IV), ss. I8I.

ISBN 978-83-66546-I6-5, online https://www.academia.edu/44068687/Inventoria_rerum_ musicalium_domum_Societatis_Iesu_in_Polonia_et_Lituania_tempore_suppressionis

$\mathrm{W}$

ostatnich latach w serii wydawniczej Fontes Musicae in Polonia, powstałej z inicjatywy Tomasza Jeża i współtworzonej przez wielu muzykologów z różnych ośrodków polskich i europejskich, ukazują się przede wszystkim publikacje związane z muzycznym dziedzictwem jezuitów z terenów dawnej Rzeczpospolitej ${ }^{1}$. Seria ta obejmuje nie tylko edycje źródłowo-krytyczne (seria C), lecz także książki (seria B) oraz katalogi i materiały pomocnicze do badań muzykologicznych (seria A). Na podkreślenie zasługuje fakt, że wszystkie publikacje ukazują się zarówno w tradycyjnej wersji papierowej, jak i w wersji elektronicznej w wolnym dostępie.

W ramach serii $A$, redagowanej przez Tomasza Jeża i Katarzynę Spurgjasz, w 1. 20I7-20 opublikowano cztery tomy: katalog wrocławskiej kolekcji Daniela

$1 \mathrm{~W}$ serii publikowane są rezultaty projektu badawczego NPRH pt. „Repertuar muzyczny Towarzystwa Jezusowego w Rzeczpospolitej Obojga Narodów (1565-1773)".
Sartoriusa (I6I2-7I) przygotowany przez Tomasza Jeża ${ }^{2}$, katalog zawartości tabulatury organowej z biblioteki ewangelickiego kościoła Kripplein Christi we Wschowie w opracowaniu Sonii Rzepki³ ${ }^{3}$ katalog muzykaliów kościoła pw. Wniebowzięcia NMP w Kłodzku sporządzony przez Martę Pielech i Iwonę Januszkiewicz-Rębowskąa a także recenzowaną tutaj publikację zawierającą wypisy z inwentarzy jezuickich z I773 i I774 r., której autorem jest Andrea Mariani.

Andrea Mariani jest historykiem związanym z Uniwersytetem im. Adama Mickiewicza w Poznaniu. Jego zainteresowania naukowe koncentrują się wokół dziejów Za-

2 Tomasz Jeż, Danielis Sartorii Musicalia Wratislaviensia, Warszawa 2017 (= Fontes Musicae in Polonia, A/I).

3 Sonia Rzepka, Tabulatura Organi ex Bibliotheca Fraustadiensi ad Praesepe Christi, Warszawa 2018 (= Fontes Musicae in Polonia, A/II).

4 Marta Pielech, Iwona Januszkiewicz-Rębowska, Musicalia Collegii Glacensis Societatis Jesu, Warszawa 2019 (= Fontes Musicae in Polonia, A/III). 